University of Nebraska - Lincoln

DigitalCommons@University of Nebraska - Lincoln

Architecture Program: Faculty Scholarly and

Creative Activity

Architecture Program

2006

\title{
How Does Increasing Population and Diversity Affect Resident Satisfaction? A Small Community Case Study
}

James J. Potter

University of Nebraska - Lincoln, jpotter2@unl.edu

Rodrigo Cantarero

University of Nebraska-Lincoln, rcantarero1@unl.edu

Follow this and additional works at: https://digitalcommons.unl.edu/arch_facultyschol

Part of the Architecture Commons

Potter, James J. and Cantarero, Rodrigo, "How Does Increasing Population and Diversity Affect Resident Satisfaction? A Small Community Case Study" (2006). Architecture Program: Faculty Scholarly and Creative Activity. 9.

https://digitalcommons.unl.edu/arch_facultyschol/9

This Article is brought to you for free and open access by the Architecture Program at DigitalCommons@University of Nebraska - Lincoln. It has been accepted for inclusion in Architecture Program: Faculty Scholarly and Creative Activity by an authorized administrator of DigitalCommons@University of Nebraska - Lincoln. 


\title{
How Does Increasing Population and Diversity Affect Resident Satisfaction? A Small Community Case Study
}

\author{
James Potter and Rodrigo Cantarero
}

University of Nebraska-Lincoln

JAMES POTTER has been a long-time leader in the Environmental Design Research Association, having served as its president, and published extensively in related journals. His recent research has focused on measuring the quality of life in communities that have been affected by the influx of immigrant workers.

RODRIGO CANTARERO is an associate professor with the Community and Regional Planning Program at the University of Nebraska-Lincoln. He has been an active researcher in racial and ethnic minority health risk behaviors, immigration, and quality of life issues in small towns in Nebraska.

ABSTRACT: This study examines the quality of life in Crete, Nebraska, with the specific purpose of identifying the factors that play the largest role in determining residential satisfaction. The survey asks a number of questions pertaining to different aspects of living in Crete. The survey is adapted from a survey previously used for a similar study in Schuyler, Nebraska. Focus groups are used to identify key issues in Crete and make adjustments to the questionnaire. Cronbach's alpha is used to test the reliability of the topical variables, and index variables are created, which are used in the subsequent analysis. Using residential satisfaction as the dependent variable, stepwise multiple linear regressions are performed independently for the total population, the new arrivals, and the long-time resident groups. The findings of this study indicate that stressors and sociocultural issues are the significant contributors to the overall community's residential satisfaction.

Keywords: quantitative study; residential satisfaction; comparison of immigrants

Authors' note: We would like to acknowledge numerous people who have contributed their assistance to the research effort: Steve Larrick, Stacy Kroft, Heather Keele, and Amy Boren. Please address correspondence concerning this article to James Potter, University of Nebraska-Lincoln; jpotter2@unl.edu. 
During the past 10 years, many communities throughout the Midwest have experienced a significant increase in the diversity of their populations (U.S. Census Bureau, Difference in Diversity, various years). What was historically rural, White, and Protestant is changing in size, color, and creed. Although growth is important for community viability, it is often accompanied by growing pains (Grey \& Woodrick, 2002; Smith \& Krannich, 2000). Easing the process of change while maintaining community satisfaction can be a juggling act for even the most experienced community leaders. It is crucial for community leaders to understand the perceptions of community residents about the quality of life in the community and the factors affecting it. With this knowledge, it is possible to design community programs that will maintain or even increase resident satisfaction during these times of change.

A research project was developed to understand how various environmental factors affect the quality of life for the newly arrived residents (fewer than 5 years in the community) and long-time residents (more than 15 years in the community) of a small, rural community in southeastern Nebraska called Crete. The study focused on housing satisfaction and how it relates to other quality of life factors. The study was a collaborative effort between the city of Crete and a University of Nebraska-Lincoln College of Architecture study team. The city of Crete and Doane College provided assistance in coordinating meetings and focus-group sessions and recruiting interviewers for data gathering. Although the study dealt with a wide range of quality of life issues, this article will concentrate on the issues relating to residential satisfaction.

Various researchers (Amerigo \& Aragones, 1990; Campbell, Converse, \& Rodgers, 1976; Canter, 1983; Francescato, Weidemann, \& Anderson, 1989; Marans \& Rodgers, 1975; Rapoport, 1977; Rojek, Clemente, \& Summers, 1975; Wasserman, 1982) have posited ways to conceptualize how individuals evaluate the environment. Rapoport (1977) believes that people evaluate environments against an image (or cognitive schemata) of what they would like it to be (an ideal). These evaluative schemata are influenced by their previous experience, adaptation level, and cultural values. Canter's (1983) premise is that satisfaction with places by their inhabitants is a reflection of the degree to which they feel it is helping them achieve their goals. He argues that these goals have two major referents: the social and the physical environment. Rojek et al. (1975), Marans and Rodgers (1975), and Campbell et al. (1976) have said that people make decisions based on subjective assessments of a place. Therefore, one's assessment of 
a place will be dependent on how it is perceived, the attributes of the place, and the standard of comparison against which it is judged (e.g., personal needs, expectations, aspirations, reference group, etc.). Finally, both Francescato et al. (1989) and Amerigo and Aragones (1990) base their conceptualizations on the model of attitudes developed by Fishbein and Ajzen (1975). They view a person's evaluation of a place as a complex, multidimensional, global appraisal combining cognitive, affective, and conative (or behavioral) facets. Thus, conceptualization of how individuals evaluate their environment converges on the idea that it involves more than one variable and depends on the manner in which the attribute is perceived and the standard of reference to which it is compared.

The study of satisfaction dates to the 1940s and is currently used in many disciplines such as housing, consumer satisfaction, marketing, landscape architecture, and the health and medical fields (Davies, 1945). There are two general approaches to empirical research about residential satisfaction (Amerigo \& Aragones, 1990). One approach is to view residential satisfaction as one criterion of quality of life (Cutter, 1982; Galster \& Hesser, 1981; Goudy, 1977; Marans \& Rodgers, 1975; Weidemann \& Anderson, 1982). A second approach is to view residential satisfaction as a predictor of a variety of behaviors (e.g., residential mobility or modification; Newman \& Duncan, 1979; Premius, 1986; Speare, 1974). The present research emphasizes the former approach.

Campbell et al. (1976) define level of satisfaction as the perceived discrepancy between aspiration and achievement, or what Morris and Winter $(1975,1978)$ referred to as "housing deficit," which is heavily influenced by past experience and current expectations. Housing needs and aspirations, moreover, change as households progress through different life cycles (Rossi, 1955) or life courses (Elder, 1985; McHugh, Hogan, \& Happel, 1995). Both Marans and Rodgers (1975) and Campbell et al. (1976) have found that the overall quality of life or life satisfaction is influenced by a variety of social and physical domains (e.g., family, job, religious affiliation, residence, neighborhood, community, etc.). A person's overall quality of life can be conceptualized as a combination of these numerous domains. This is not to suggest that this is simply an additive process. There may be many interacting or competing influences between domains.

As modeled by Marans and Rodgers (1975) and Campbell et al. (1976), the process of evaluating a domain begins with the objective attributes. We all live in an objective world, but we make decisions based on our sub- 
jective assessments of a situation. Therefore, our assessment of a domain will be dependent on how we perceive the domain attributes and the standard against which we judge them. The standard of comparison might be based on personal needs, expectations, aspirations, reference group, and so forth. Our perception of the attributes will be influenced by personal characteristics such as experience, social standing, and personality. A person's evaluation of the domain will conclude with an assessment, which in turn affects our level of satisfaction with that domain.

Satisfaction as a measure has been criticized. As previously discussed, satisfaction is a subjective response to an objective environment. As such, measures of satisfaction have been met with skepticism and criticism:

(1) reported satisfaction tends to be uniformly high and therefore cannot be assumed to indicate the "true" state of affairs; (2) subjective measures of satisfaction do not correlate with objective measures of context and behavior, therefore they cannot be considered valid measures of the objective reality; (3) satisfaction with an object varies, for the same individual or social group, with time and with personal and social norms and expectations, thus it is too fickly an indicator on which to base action; (4) satisfaction tends to be higher the lower the respondent's awareness of "better" alternatives, thus it tends to reflect unenlightened assessments on which policy and decisions should not be based; and (5) focusing on satisfaction - rather than attacking "real" problems - may result in sub-optimal environments. (Francescato, Weidermann, \& Anderson, 1987, p. 48)

Francescato et al. (1987) provided responses to these criticisms and concluded that although the criticisms point to limitations that should be taken into account when interpreting results, they seem to warrant using the construct of satisfaction. In addition, Campbell et al. (1976) concluded that exaggerated skepticism of subjective responses is not warranted based on extensive consideration of (among others) the following: (a) the reliability and validity of measures, (b) the comparison between objective and subjective indicators of well-being, (c) the levels of reality of domains being assessed, and (d) the analytical intentions (Anderson \& Weidmann, 1997). Finally, objective measures alone do not adequately explain satisfaction (Galster \& Hesser, 1981; Weidemann \& Anderson, 1982), and satisfaction addresses evaluative factors (Guest \& Lee, 1983).

In a wide variety of publications, Sue Weidemann, Guido Francescato, and James Anderson (Anderson \& Weidemann, 1997; Francescato et al., 1989; Weidemann \& Anderson, 1985) have explored residential satisfac- 
tion. Francescato, Weidermann, and Anderson (1986) defined satisfaction as an atitude and stated that affective, cognitive, and behavioral variables affect satisfaction. The affective component is both emotional and evaluative and is composed of multiple reactions that form a "global representation of the affective responses of people to the social-physical environment in which they live" (Weidemann \& Anderson, 1985). Cognitive are aspects of perception and beliefs (e.g., about the physical environment, other residents), and behavioral aspects measure behavioral intentions (e.g., desire for staying or moving, recommendations to friends). Therefore, it is clear that as a construct, resident satisfaction must be both conceived and interpreted as multifaceted. Accepting this interpretation of satisfaction would indicate that a single question would be an insufficient measure of satisfaction as a multifaceted construct. Anderson and Weidemann (1997) addressed this issue by using a list or index of four questions reflecting affective, cognitive, and behavioral aspects of overall satisfaction with housing:

How satisfied are you with living here?

How long do you want to live in this community?

If you move again, would you like to live in another place like this?

Would you recommend this place to one of your friends?

The model of residential satisfaction proposed by Francescato et al. (1986) described a six-domain taxonomy of predictor variables for resident satisfaction, including the following: objective environmental attributes, individual characteristics, behavioral and normative beliefs, perception, emotions, and behavioral intentions. Variables, in such a view, need to include not only the physical environment but also aspects such as management, community, and health. These domains contribute to and comprise attitudes toward residential satisfaction.

Several variables have been found to affect residential satisfaction, including culture (Deshmukh, 1995; Guney, 1997; Smith \& Krannich, 2000); life satisfaction (Amerigo, 1990; Pruitt, 1978; Rohe \& Basolo, 1997; Theodori, 2001); neighborhood and environs, house and neighbors (Amerigo \& Aragones, 1990; Basolo \& Strong, 2002; Kim, 1997; Taylor, 1993, 1995); and social factors (Filkins, Allen, \& Cordes, 2000; Goudy, 1977). Goudy (1977) found that social dimensions were more important in determining residential satisfaction than previously thought. Other factors have been found to alter resident perception, including race (Howarth, 2001; Painter, Gabriel, \& Myers, 2001). 
The purpose of our research is to explore the quality of life characteristics that influence the residential satisfaction of long-time residents compared with those of newly arrived residents. Residential satisfaction was measured using the four questions suggested by Anderson and Weidemann (1997) discussed above as well as the additional questions noted in the appendix at the end of this article. As the preceding discussion suggests, the conceptual framework out of which our research proceeds is that of Marans and Rodgers (1975), Campbell et al. (1976), and Francescato et al. (1989). Based on the prior work, it is clear that overall quality of life is affected by a variety of domains. The four major domains we intend to investigate are physical, social and cultural, economic, and public services. First, the physical environment includes variables such as housing conditions, the neighborhood, and other elements. Second, the social and cultural aspects of life, such as family relations, neighbors, and a sense of community are contributing factors. Third, economic circumstances such as employment and retail conditions also become factors contributing to the satisfaction of residents. The fourth set of factors is the public services that residents have access to, such as police and fire protection, recreation, and transportation. A combination of these characteristics plays a role in the experience of an individual's life. Each of these characteristics may vary in its level of importance for the individual resident; in turn, aggregate combinations of these characteristics affect the overall quality of life for the community. Because the residents' perception of conditions is subjective, it is important to remember that they may vary from the actual conditions. We hypothesize that the long-time residents and newly arrived residents will differ with regard to the quality of life characteristics they deem most important to their residential satisfaction.

\section{BACKGROUND}

The United States continues to grow in diversity (U.S. Census, Differences in Diversity, various years). This growth is significant in many parts of the United States, with portions of the Midwest showing more than $100 \%$ growth. This dramatic increase of the Latino population in the Midwest is clearly seen in Nebraska, where 82 of its 93 counties experienced growth in their Hispanic populations. Although the majority of Nebraska's counties saw only a 5\% increase or less in their Latino populations, 9 counties saw an increase of $5 \%$ to $10 \% ; 5$ counties experienced a $10 \%$ to $50 \%$ increase; and 2 counties grew more than $50 \%$ (U.S. Census Bureau, Percent Change, various years). This rapid change in diversity puts large 
amounts of stress on communities that are traditionally fairly homogeneous. Crete, Nebraska (population 5,200), located in Saline County, is one of the communities affected by this sudden increase in diversity. In 2001, a local pork-processing plant announced it would be increasing its workforce from 1,200 to 1,650 employees. Meat processing is not a job typically sought by many members of the Anglo population (Grey \& Woodrick, 2002). To fill these jobs, meat-processing plants have been hiring more and more non-Anglo workers (Grey \& Woodrick, 2002). In Crete, workers come from Vietnam, Korea, Laos, Croatia, Serbia, and Iraq; the vast majority of them, however, are foreign-born Hispanics or Latinos. According to the U.S. Census Bureau between 1990 and 2000 (Table P4 in 1990, Table P009 in 2000), Crete's population grew by 1,187 persons, and the Hispanic and Latino population grew by 911 persons ( $81 \%$ of the population growth for the county; U.S. Census Bureau, 1990, 2000).

The demographic changes occurring in Crete appear to be due to a combination of the following factors: (a) the availability of employment opportunities at Farmland, a pork-processing plant; (b) the resettlement of refugees through organizations located in Lincoln, the capital of Nebraska, 24 miles away; and (c) word-of-mouth invitations by Crete residents to their friends, families, and acquaintances. The following is a brief outline of the city's history and the factors contributing to its growth:

- 1869 - Crete Mills (a division of Lauhoff Grain Company) was established. It produces food grain products.

- 1870 - Crete was founded.

-1872-Doane College was founded.

-1910 - Douglas Manufacturing opened and manufactures voting equipment.

- 1965-Allen Products Company (now Friskies Pet Care Company) was established. It manufactures all-meat dog food.

-1975 — Farmland Foods, Inc., was established. It processes pork for the national and international market.

- 1984 - First 12 to 15 Vietnamese employees hired at Farmland.

- 1989 to 1990 - More Vietnamese families came to Crete for resettlement.

- Early 1990s-Hispanics start moving to Crete from other meatpacking communities.

- Late 1990s-Bosnians moved to Crete through resettlement programs.

- December 2000 - A 25\% jump in the production workforce since December 1999.

- December 17, 2000-Farmland has an ongoing expansion and an \$11-an hour starting wage. 
The number of employees is 1,300. Expansion for the plan includes adding a second slaughter shift and many more jobs numbering in the hundreds. According to Farmland officials who participated in a meeting with the research team, $50 \%$ of the workers currently live in Crete and Wilber, and the other $50 \%$ live in Lincoln.

Crete is not alone in its experience of increased migration; in fact, similar increases are occurring throughout the Midwest. The reasons for this migration are complex, but economics are frequently a central factor (Cantu, 1995; Grey \& Woodrick, 2002). Crete, like many other communities, has job opportunities to offer these new residents.

\section{METHOD}

This study examined the quality of life in Crete, Nebraska, specifically looking at residential satisfaction. A survey was developed asking a number of questions pertaining to different aspects of living in Crete. Focus groups were used to identify key issues in the community and make adjustments to the questionnaire. The survey was adapted from a survey that was previously used for a quality of life study in Schuyler, Nebraska. The sample was drawn from two groups of randomly selected Census 2000 blocksthose with five or more racial or ethnic minorities (most likely to be immigrants) and the balance of census blocks - to obtain roughly 50 surveys from each group of blocks. Each block was canvassed, and one randomly chosen individual per household meeting our criteria ( 5 or fewer years living in the town for the newly arrived and 15 or more years for long-time residents, both 18 years of age or older) was interviewed in the language of his or her choice (Spanish or English). This analysis identified the factors that played the largest role in determining residential satisfaction. The responses of the residents as a whole, the long-time residents, and the new arrivals are separately explored.

Table 1 shows that the long-term residents are predominately White (93.6\%), whereas more than half of the new arrivals residents claim a race other than White $(52.8 \%)$ or Black $(1.9 \%)$. The majority of newly arrived residents are under the age of 39 (85\%), whereas $78.6 \%$ of the long-time residents are above 40 years of age; these residents are also more likely to be married than the new arrivals are. Long-term residents are slightly more likely to be college educated, with $52 \%$ having at least some college education; new-arrival residents claim a $42.3 \%$ college attendance. Only $4.5 \%$ of new-arrival households earn more than $\$ 40,000$, whereas $43.9 \%$ of long-term households surpass the $\$ 40,000$ mark.

The method used in this study can be summarized by the four phases discussed below. 
TABLE 1

Sample Demographics $(N=100)$

\begin{tabular}{|c|c|c|c|}
\hline \\
\hline Variable & Values & $\%$ New Arrivals & $\%$ Long Term \\
\hline \multirow[t]{2}{*}{ Sex } & Male & 43.4 & 36.2 \\
\hline & Female & 56.6 & 63.8 \\
\hline \multirow[t]{2}{*}{ Age } & 20 to 39 & 84.9 & 21.7 \\
\hline & 40 to 99 & 15.1 & 78.6 \\
\hline \multirow[t]{3}{*}{ Race } & White & 45.3 & 93.6 \\
\hline & Black & 1.9 & 2.1 \\
\hline & Other & 52.8 & 4.3 \\
\hline \multirow[t]{2}{*}{ Marital status } & Married & 41.5 & 59.6 \\
\hline & Unmarried & 58.5 & 40.4 \\
\hline \multirow[t]{5}{*}{ Schooling } & Some high school & 21.2 & 10.9 \\
\hline & High school graduate & 36.5 & 34.8 \\
\hline & Some college & 32.7 & 39.1 \\
\hline & Bachelor's degree & 9.6 & 10.9 \\
\hline & Master's or beyond & 0.0 & 4.3 \\
\hline \multirow[t]{3}{*}{ Household income } & $\$ 0$ to 9,999 & 20.5 & 0.0 \\
\hline & $\$ 10,000$ to 39,999 & 75.0 & 56.1 \\
\hline & $\$ 40,000$ and above & 4.6 & 43.9 \\
\hline
\end{tabular}

\section{PHASE I: ESTABLISHING TRUST}

The main goal of this phase was to build trust with city officials to gain their participation in the study of housing and quality of life issues. This stage allowed researchers to familiarize themselves with resources serving the general community and those serving newly arrived residents.

An initial meeting between the University of Nebraska-Lincoln research team and Crete officials marked the first of several meetings in which the information provided became the vehicle for coordinating focus groups, designing and testing the questionnaire, locating the target population, and hiring Doane College students and others as interviewers.

\section{PHASE II: IDENTIFYING ISSUES}

The primary goal of this phase was to gather information by holding and attending community meetings, conducting literature searches, collecting newspaper articles, obtaining U.S. Census data, and gathering feedback from focus groups. The literature search (i.e., newspaper articles) helped to provide a picture of the historical forces that have shaped current conditions in Crete. Furthermore, the focus groups (at least one for each target group) 
became a means of better understanding community residents' perceptions of housing and quality of life issues.

The University of Nebraska-Lincoln Research Team developed the survey instrument for Crete, using previously tested questionnaires as a baseline. In developing the questionnaire, the following elements were used to arrive at a final draft: two focus groups with new-arrival residents (fewer than 5 years), and one focus group with long-time residents (more than 15 years). Some of the issues identified by newly arrived residents included integration; communication; understanding federal and local laws, rules, and regulations; the impact of being undocumented on obtaining a driver's license, health insurance, or auto insurance; lack of transportation; and a need for diversified shopping areas.

Researchers met with the Crete collaborating team to discuss the survey draft. Input was provided by city officials, and the final changes were made. The questionnaire was tested in English and Spanish and made available to Doane College students to conduct in the community. Doane College students were trained as interviewers along with other interviewers from different research projects one of the authors was running.

\section{PHASE III: SURVEYING THE RESIDENT PERCEPTIONS}

The goal of the study was to provide an assessment of quality of life issues as perceived by newly arrived residents and the long-time residents; the stress associated with changes in the community; and how their well-being has been affected as a result of these changes. Participants of the long-time resident interview were individuals who have been living in Crete prior to January 1986. Newly arrived residents were defined as individuals who have lived in Crete since January 1996. No residents who had moved to Crete after January 1986 and before January 1996 would be interviewed. Besides meeting the resident requirement, potential participants had to meet the age requirement of being 20 years of age or older.

The sample design was a simple random sample of Census 2000 blocks of the city of Crete reporting five or more racial or ethnic minorities (to ensure that an adequate number of minorities were reported in the sample). All households in the chosen blocks were contacted, and surveys were randomly assigned to an eligible member. A total of 100 surveys were obtained, attempting to obtain equal amounts of long-term and newly arrived residents. The questionnaire used a Likert-type scale of 1 to 5 to determine level of satisfaction.

\section{PHASE IV: ANALYZING THE SURVEY RESULTS}

The data were analyzed using SPSS. Long-term and short-term residents were compared with regard to their responses to each survey question. Subsequent analysis of residential satisfaction is discussed below. 
TABLE 2

Cronbach's Alpha

\begin{tabular}{ll} 
Index Variable & Alpha \\
\hline Residential satisfaction & 0.8390 \\
Neighborhood housing concerns & 0.8540 \\
Changes in Crete & 0.8058 \\
Contributors to the current housing & 0.7410 \\
condition & \\
Physical issues & 0.7440 \\
Service issues & 0.8325 \\
Social and cultural issues & 0.7758 \\
Economic issues & 0.7166 \\
Stress factors & 0.8080 \\
Housing assistance & 0.7170 \\
\hline
\end{tabular}

\section{ANALYSIS}

The questions from the survey were grouped together based on which topic they were addressing: residential satisfaction, economy, and stress. Cronbach's alpha was then used to test the reliability of the topical scales (see Table 2). The combination of variables that produced an alpha above 0.7 was considered to be reliable topical scales. The questions that were deemed unreliable for determining resident satisfaction were dropped from subsequent analysis. The questions that tested reliable were "collapsed" into composite scores (means), or indexes. Ten indexes were created. In addition to an index variable of residential satisfaction, index variables were used in the subsequent analysis of resident satisfaction. They were neighborhood housing concerns, housing assistance, changes in Crete, contributors to the current housing conditions, physical issues, service issues, social and cultural issues, economic issues, and stressors (see appendix for a more detailed description). In addition, some variables the literature identifies as potential factors affecting residential satisfaction were also included: age, sex, income level, and education level.

Next, a stepwise multiple linear regression was conducted for all residents (see Table 3 ). The regression showed that stressors $(\beta=-0.333)$, neighborhood housing concerns $(\beta=0.235)$, service issues $(\beta=0.221)$, and social and cultural issues $(\beta=0.214)$ were significant in determining residential satisfaction. The eight other variables were not significant. 
Stepwise multiple linear regressions were also performed independently for the new arrivals and the long-time resident groups. There was a significant difference between what these two groups considered important with regard to residential satisfaction (see Tables 4 and 5). The regression for new arrivals indicated that physical issues $(\beta=0.435)$ was the most significant variable, followed by stress factors $(\beta=-0.304)$ and social and cultural issues $(\beta=0.284)$. Whereas stressors $(\beta=-0.430)$ was the main index variable determining residential satisfaction among the long-time residents, other indicators for this group were changes in Crete $(\beta=0.415)$, service issues $(\beta=0.255)$, and level of education $(\beta=0.212)$.

TABLE 3

Regression (Stepwise) of Total Sample Population

\begin{tabular}{lccc} 
Index variable & Beta $(\beta)$ & $t$ & Significance $^{a}$ \\
\hline Stress factors & -0.333 & -4.105 & 0.000 \\
Neighborhodd housing concerns & 0.235 & 3.634 & 0.001 \\
Service issues & 0.221 & 2.887 & 0.003 \\
Social and cultural issues & 0.214 & 3.355 & 0.001 \\
\hline
\end{tabular}

NOTE: Dependent variable: Residential Satisfaction Index.

a. Two-tailed test; $\mathrm{r}^{2}=0.640$.

TABLE 4

Regression (Stepwise) of New Arrival Sample Population

\begin{tabular}{lccc} 
Index variable & Beta $(\beta)$ & $t$ & Significance $^{a}$ \\
\hline Physical issues & 0.435 & 2.933 & 0.000 \\
Stress factors & -0.304 & -3.188 & 0.003 \\
Social and cultural issues & 0.284 & 3.569 & 0.001 \\
\hline
\end{tabular}

NOTE: Dependent variable: Residential Satisfaction Index.

a. 2-tailed test; $\mathrm{r}^{2}=0.698$.

TABLE 5

Regression (Stepwise) of Long-Term Sample Population

\begin{tabular}{lccc} 
Index variable & Beta $(\beta)$ & $t$ & Significance $^{a}$ \\
\hline Stress factors & $-0,403$ & -3.609 & 0,001 \\
Changes in Crete & 0.415 & 3.618 & 0.001 \\
Service issues & 0.255 & 2.346 & 0.027 \\
Education & 0.212 & 2.184 & 0.039 \\
\hline
\end{tabular}

NOTE: Dependent variable: Residential Satisfaction Index.

a. Two-tailed test; $\mathrm{r}^{2}=0.736$. 
Further analysis was done to explore the relationship between residential satisfaction and the individual support issues variables. Using Pearson correlations, we first explored the relationship for the entire sample population, followed by our long-term sample population and the newly arrived sample population. A Pearson correlation (r) was generated for the entire population. It showed significant correlations between the residential satisfaction index and the questions related to support issues. The strongest significant ( 0.01 or less) correlation $(\mathrm{r}=0.452)$ in the set was between residential satisfaction and the item "Social organizations provide support for me when I am in need," closely followed by "I can rely on friends for support in times of need" $(r=0.406)$. A multiple linear regression was then carried out to determine which of these questions better accounted for variance in residential satisfaction. Again, "social organizations provide support for me when I am in need" ( $\beta=0.194)$ proved to be the most significant statement with regard to satisfaction, followed by "I can rely on friends for support in times of need" ( $\beta=0.166)$. However, when the correlation was run for long-term residents and new arrivals separately, it tested significant only for the longterm residents $(r=0.640$ and $r=0.599$ at significance $=0.001)$; not to our surprise, the regression was significant only for the long-term residents $(\beta=$ 0.319 and $\beta=0.329$, respectively).

We also looked at the correlation between the item "my overall level of stress" and the questions used to construct the variable support factors. We determined that both of the support questions were inversely correlated to "my overall level of stress," but only one generated a significant inverse correlation: "Social organizations provide support for me when I am in need" ( $\mathrm{r}$ $=-0.304$ at 0.01 significance level). Moreover, when split by long-term and new arrivals, only the long-term residents maintained the significant correlation ( $\mathrm{r}=-0.396$ at 0.01 significance).

\section{DISCUSSION}

The findings of this study indicated that stressors and social and cultural issues were the significant contributors to the overall community's residential satisfaction. The stressors index variable includes such items as employment, income level, ability to communicate, isolation, discrimination, tension with neighbors, crime, social and cultural differences, and lack of transportation. The social and cultural issues included cooperation among neighbors, crosscultural understanding, and the sense of community in Crete. This is an area where community leadership could join hands with social and human service organizations in increasing the quality of life. City officials could collaborate with human service providers and church groups in the community to provide 
support and help ease the interaction between long-term residents and new arrivals. If support systems were created within neighborhoods, and crosscultural education was provided, residential satisfaction might increase. Support groups could be set up in the community through churches, libraries, and neighborhood meetings; social events could be planned that would create interaction among the newly arrived and long-term residents (Cherniss, 2002; O'Donnell et al., 1998). Housing concerns and services were also identified as an influential source of residential satisfaction. City officials could form coalitions with planners and designers to generate ideas for neighborhood cleanup and to find how to deal with perceived problems such as trailer parks and excess cars (O’Donnell et al., 1998; Wolff, 2001).

When looking at residential satisfaction through the eyes of the newly arrived residents, it is clear that physical issues are of the utmost importance (adequacy of public services, overall attractiveness of the neighborhood and visibility of trailer parks, air quality, the quality of the street and parking, and accessibility). This could be the result of several factors. It is possible that the newly arrived residents have not lived in Crete long enough to notice how the town is changing; or perhaps they are not aware of the services provided by the community. Another possibility contributing to the salience of physical conditions as extremely important to newly arrived residents is that living conditions overall may have been superior in the communities from which they migrated.

Long-term residents were most significantly swayed by stressors. This might be a reflection of the lesser adaptability of the long-term residents to fast changes in the community (e.g., not being understood, being among culturally different people); immigrants, on the other hand, are accustomed to having to quickly adapt to new environments. The other variables that were important to long-time residents included changes in Crete and service issues. The former is related to difficulty in adapting to changes (and seeing changes in the status quo as threatening, not as an unusual reaction), whereas the latter relates to access to quality education and health care, access to public transportation, English as a second language, police protection, and access to basic supplies and retail. Finally, the level of education was a significant variable. It is not unusual to find higher level of education with increased acceptance and adaptability to change to things that are different.

In 1954, Abraham Maslow, an American psychologist, published a theory about the sources of human motivation. He contended that humans are motivated to behave in certain ways to fulfill their developmental needs (Maslow, 1954). Maslow then arranged these developmental needs into a hierarchical pyramid, in which the most basic physical needs comprise the bottom of the pyramid. The next step up is the need for safety and secu- 
rity. The following step is the need for love and belongingness, followed by the need for self-esteem. At the top of the pyramid, then, is the need for self-actualization (Maslow, 1954). According to Maslow, the ultimate goal of humanity is to achieve self-actualization, but a person cannot attain this without first fulfilling the lower order needs. For Maslow, humanity is in a constant state of seeking fulfillment of its needs, starting with the lowest, basic needs and ending with the highest need for self-actualization. The state of being self-actualized allows for a "more efficient" perception of reality because the individual is no longer distracted by unfulfilled needs (Maslow, 1954). Maslow's theory of human motivation and development is believed to account for an individual's perception of his or her quality of life, both on national and local levels (Hagerty, 1999; Sirgy, 1986).

When examining the responses of the residents of Crete, it is interesting to note the differences between the responses of the long-term residents and newly arrived residents in light of Maslow's theory. According to the responses of the newly arrived residents, their primary concerns are with the physical issues, such as housing conditions, addressed in the survey. However, the long-term residents were more concerned with the ways in which the community could improve and better serve the higher order needs of the residents. The reasons for this discrepancy in perceived satisfaction could be related to Maslow's theory. For example, the newly arrived residents could still be adjusting to their new environment or be planning on migrating again soon. They may feel uneasy and insecure about their new community; they may not feel like they belong yet. Long-term residents have been settled in Crete for at least 15 years. For the most part, they are secure and have their basic needs met; they feel that they belong in the community. They seem to be focused more on improving the community. It could be that they have been able to meet their lower order needs and can now focus on the self-actualization need or, if you will, "community actualization."

Race could play a part in the different views of the residents. Studies have shown that there is a $12 \%$ to $30 \%$ gap in the homeownership rate between White residents and Latino residents in the United States (Borjas, 2002; Painter et al., 2001). This gap can be attributed to several factors, including length of stay in the United States, lower levels of income and education, area of residence, and immigrant status (Borjas, 2002; Painter et al., 2001).

The findings of this study strongly reflect the findings of the Filkins et al. (2000) study, in which they state, "The respondents were most satisfied with communities that they considered to be friendly, trusting, and supportive. Also, the greater their satisfaction with social/spiritual factors, the greater their satisfaction with the community." 


\section{FUTURE IMPLICATIONS}

The next step that could be taken in this study would be to look more closely at the index variables that affected residential satisfaction, specifically physical issues, support factors, housing concerns, and service issues. This study could result in more in-depth results depicting the degree to which each index variable affects residential satisfaction. It would also be interesting to do a follow-up survey of this sample in 10 to 15 years to see if their indications of residential satisfaction have changed, supporting Maslow's (1954) theory of human development and motivation.

\section{APPENDIX \\ INDEX VARIABLES}

Residential satisfaction. The residential satisfaction index included the following questions:

I am satisfied with the size of my residence.

I am satisfied with the level of safety from fire while in my residence.

I am satisfied with the level of safety from being a victim of a crime while in my residence.

I am satisfied with the amount of area for outdoor activity at my residence.

I have adequate off-street parking.

I am satisfied with the overall amount I pay for rent or mortgage and utilities.

I am satisfied with the overall physical condition of my residence.

I am bothered by noise from nearby residence or businesses (reversed scale).

I have sufficient privacy from my neighbors.

I have enough privacy from others in my residence.

The residence I live in provides a healthy environment.

The struggle for a better house is a source of stress for me (reversed scale).

The number of people living in my residence is a source of stress for me (reversed scale). 
I would like to continue living in Crete as long as possible.

I would recommend my immediate neighborhood to a friend.

Neighborhood housing concerns.

The quality of housing in my neighborhood.

Maintenance of housing in my neighborhood.

\section{Changes in Crete.}

Has a sense of community gotten better or worse?

Has the quality of housing gotten better or worse?

Has the availability of housing gotten better or worse?

Has the affordability of housing gotten better or worse?

Have cultural relations gotten better or worse?

Have crime conditions gotten better or worse?

Have crowding conditions (number of persons in a residence) gotten better or worse?

Have economic conditions gotten better or worse?

Physical issues. The level of satisfaction with the following:

The overall visual attractiveness of the neighborhood.

The adequacy of public services.

The garbage collection.

The level of street maintenance in the neighborhood.

The traffic that goes through the neighborhood.

The parking of cars in the neighborhood.

The accessibility for handicapped.

The visibility of trailer parks.

Service issues.

Access to convenient public transportation.

Adequacy of health services.

Quality of education services.

Availability of English as a second language. Access to recreation services.

Availability of entertainment (e.g., restaurants, movies, etc.).

Affordability of day care services.

The level of police protection.

The level of fire protection.

Accessibility of basic supplies (e.g., food).

Accessibility of retail.

Social and cultural issues. 
Cooperation among neighbors.

Cross-cultural understanding.

The sense of community in Crete.

Economic issues.

Availability of employment for people in Crete.

Crete's ability to attract new businesses.

The well-being of businesses.

The overall economic condition of people.

Stress factors.

Tension with my neighbors is a source of stress.

My level of income is a source of stress.

Life in Crete is very stressful.

An inability to communicate with others is a source of stress for me.

Living in Crete is beneficial for my family (reversed scale).

My job (or lack of a job) is a source of stress.

Feeling isolated is a source of stress for me.

I feel pressure to do better, advance, or succeed.

Racial discrimination is a source of stress for me.

Crime in Crete is a source of stress for me.

The social or cultural differences of people in the community are a source of stress.

Lack of transportation is a source of stress for me.

I am satisfied with my level of income (reversed scale).

Support factors.

A variety of social organizations provide either financial or social support for me when I am in need.

I can rely on friends for support in times of need.

\section{REFERENCES}

Amerigo, M. (1990). The perception of residential environment and environment role. In H. Pamir, V. Iuramoglu, \& N. Teymur (Eds.), Culture, Space and History (Vol. 5, pp. 337-342). Ankara, Turkey: Middle East Technical University, Faculty of Architecture. Amerigo, M., \& Aragones, J. (1990). Residential satisfaction in council housing. Journal of Environmental Psychology, 10, 313-325. 
Anderson, J., \& Weidemann, S. (1997). Developing and utilizing models of resident satisfaction. In G. Moore \& R. Marans (Eds.), Advances in Environment, Behavior, and Design (Vol. 4, pp. 287-314). New York: Plenum.

Basolo, V., \& Strong, D. (2002). Understanding the neighborhood: From residents' perceptions and needs to action. Housing Policy Debate, 13, 83-105.

Borjas, G. J. (2002). Homeownership in the immigrant population. Journal of Urban Economics, 52, 448-476.

Campbell, A., Converse, P., \& Rodgers, W. (1976). The Quality of American Life: Perception, Evaluations and Satisfactions. New York: Russell Sage.

Canter, D. (1983). The purposive evaluation of places: A facet approach. Environment and Behavior, 15(6), 659-699.

Cantu, L. (1995). The peripherialization of rural America: A case study of Latino migrants in America's heartland. Sociological Perspectives, 38, 399-414.

Cherniss, C. (2002). Emotional intelligence and the good community. American Journal of Community Psychology, 30, 1-11.

Cutter, S. (1982). Residential satisfaction and the suburban homeowner. Urban Geography, 3, 315-327.

Davies, V. (1945). Development of a scale to rate attitudes of community satisfaction. Rural Sociology, 10, 246-255.

Deshmukh, J. (1995). Housing satisfaction: A cross-cultural study of married student housing. In J. Nasar, P. Grannis, \& K. Hanyu (Eds.), Proceedings of the 26th Annual Environmental Design Research Association Conference (p. 169). Boston, MA: Environmental Design Research Association.

Elder, G. H., Jr. (Ed.). (1985). Life Course Dynamics. Ithaca, NY: Cornell University Press.

Filkins, R., Allen, J. C., \& Cordes, S. (2000). Predicting community satisfaction among rural residents: An integrative model. Rural Sociology, 65, 72-86.

Fishbein, M., \& Ajzen, I. (1975). Belief, Attitude, Intention, and Behavior: An Introduction to Theory and Research. Reading, MA: Addison-Wesley.

Francescato, G., Weidemann, S., \& Anderson, J. R. (1986, July). Residential satisfaction and residential quality: An overview of recent applications. Paper presented at the $21 \mathrm{st}$ International Congress of Applied Psychology, Jerusalem, Israel.

Francescato, G., Weidemann, S., \& Anderson, J. R. (1987). Residential satisfaction: Its uses and limitations in housing. In W. van Vliet, H. Choldin, W. Michelson, \& D. Popenoe (Eds.), Housing and Neighborhoods: Theoretical and Empirical Contributions (pp. 43-57). New York: Greenwood.

Francescato, G., Weidemann, S., \& Anderson, J. R. (1989). Evaluating the built environment from the users' point of view: An attitudinal model of residential satisfaction. In W. Preiser (Ed.), Building Evaluation (pp. 181-198). New York: Plenum.

Galster, G., \& Hesser, G. (1981). Residential satisfaction. Compositional and contextual correlates. Environment and Behavior, 13, 735-758.

Goudy, W. J. (1977). Evaluations of local attributes and community satisfaction in small towns. Rural Sociology, 42, 371-382.

Grey, M., \& Woodrick, A. (2002). Unofficial sister cities: Meatpacking labor migration between Villachuato, Mexico, and Marshalltown, Iowa. Human Organization, 61, 364 376.

Guest, A. M., \& Lee, B. A. (1983). Sentiment and evaluation as ecological variables. Sociological Perspectives, 26, 159-184. 
Guney, Y. (1997, May). The evaluation of high-rise residents'satisfaction in Turkey. Paper presented at the Environmental Design and Research Association 28th Annual Conference, Montreal, Canada.

Hagerty, M. (1999). Testing Maslow's hierarchy of needs: National quality-of-life across time. Social Indicators Research, 46, 249-271.

Howarth, C. S. (2001). Towards a social psychology of community: A social representations perspective. Journal for the Theory of Social Behaviour, 31, 223-238.

Kim, S. (1997, May). Outdoor environment satisfaction: Contributions of landscape design to multi-family housing residents' satisfaction. Paper presented at the Environmental Design and Research Association 28th Annual Conference, Montreal, Canada.

Marans, R., \& Rodgers, S. (1975). Toward an understanding of community satisfaction. In A. Hawley \& V. Rock (Eds.), Metropolitan America in Contemporary Perspective. New York: Halsted.

Maslow, A. (1954). Motivation \& Personality. New York: Harper \& Row.

McHugh, K. E., Hogan, T. D., \& Happel, S. K. (1995). Multiple residence and cyclical migration: A life course perspective. Professional Geographer, 47(3), 251-267.

Morris, E. W., \& Winter, M. (1975). A theory of family housing adjustment. Journal of Marriage and the Family, 37, 79-88.

Morris, E. W., \& Winter, M. (1978). Housing, Family, and Society. New York: John Wiley.

Newman, S., \& Duncan, G. (1979). Residential problems, dissatisfactions and mobility. Journal of American Planning Association, 45, 106-112.

O’Donnell, J., Ferreira, J., Hurtado, R., Ames, E., Floyd, R., \& Sebren, L. (1998). Partners for change: Community residents and agencies. Journal of Sociology and Social Welfare, 25, 133-151.

Painter, G., Gabriel, S., \& Myers, D. (2001). Race, immigrant status, and housing tenure choice. Journal of Urban Economics, 49, 150-167.

Premius, H. (1986). Housing as a social adaptation process: A conceptual scheme. Environment and Behavior, 18, 31-52.

Pruitt, L. (1978). The influence of residential domain satisfaction and life domain satisfactions on overall satisfaction with quality of life. In W. Rogers \& W. Ittelson (Eds.), New Directions in Environmental Design Research: Proceedings of the 9th Annual Environmental Design Research Association Conference (pp. 226-238). Tucson, AZ: Environmental Design Research Association.

Rapoport, A. (1977). Human Aspects of Urban Form. Oxford, UK: Pergamon.

Rohe, W., \& Basolo, V. (1997). Long-term effects of home ownership on the self-perceptions and social interaction of low-income persons. Environment and Behavior, 29(6), 793-819.

Rojek, D. A., Clemente, F. R., \& Summers, G. A. (1975). Community satisfaction: A study of contentment with local services. Rural Sociology, 40(2), 177-192.

Rossi, P. H. (1955). Why Families Move. Glenco, IL: Free Press.

Sirgy, M. (1986). A quality-of-life theory derived from Maslow's developmental perspective: "Quality" is related to progressive satisfaction of a hierarchy of needs, lower order and higher. American Journal of Economics and Sociology, 45, 329-341.

Smith, M., \& Krannich, R. (2000). "Culture clash" revisited: Newcomer and longer-term residents' attitudes toward land use, development, and environmental issues in rural communities in the Rocky Mountain West. Rural Sociology, 65, 396-421.

Speare, A. (1974). Residential satisfaction as an intervening variable in residential mobil- 
ity. Demography, 11, 173-188.

Taylor, P. (1993). Geographical scales of residential satisfaction for older adults: A comparison of dwelling and neighborhood satisfaction. In R. Feldman, G. Hardie, \& D. Saile (Eds.), Power by Design: Proceedings of the 24th Annual Environmental Design Research Association Conference (pp. 114-118). Chicago: Environmental Design Research Association.

Taylor, P. (1995). Social and environmental contexts of aging in place. In J. Nasar, P. Grannis, \& K. Hanyu (Eds.), Proceedings of the 26th Annual Environmental Design Research Association Conference (pp. 107-112).Boston, MA: Environmental Design Research Association.

Theodori, G. (2001). Examining the effects of community satisfaction and attachment on individual well-being. Rural Sociology, 66, 618-628.

U.S. Census Bureau. (1990). 1990 Summary Tape File 1. Retrieved December 7, 2002, from http:// factfinder.census.gov/home/saff/main.html? lang=en

U.S. Census Bureau. (2000). Hispanic or Latino, and not Hispanic or Latino by race, Census 2000 Summary File 1. Retrieved December 7, 2002, from http://factfinder.census. gov/home/saff/main.html?_lang=en

U.S. Census Bureau, Difference in Diversity. (various years, 1990 to 2000). Hispanic or Latino origin and all races. Mapping Census 2000: The Geography of U.S. Diversity. Retrieved December 7, 2002, from http://www.census.gov/population/cen2000/atlas/ censr01-104.pdf

U.S. Census Bureau, Percent Change. (various years, 1990 to 2000). Hispanic or Latino origin all races. Mapping Census 2000: The Geography of U.S. Diversity. Retrieved December 7, 2002, from http://www.census.gov/population/cen2000/atlas/censr01-111.pdf

Wasserman, I. M. (1982). Size of place in relation to communityattachment and satisfaction with community services. Social Indicators Research, 11, 421-436.

Weidemann, S., \& Anderson, J. (1982). Residents'perceptions of satisfaction and safety: A basis for change in multifamily housing. Environment and Behavior, 14(6), 695-724.

Weidemann, S., \& Anderson, J. (1985). A conceptual framework for residential satisfaction. In I. Altman \& C. Werner (Eds.), Home Environments (pp. 153-182). New York: Plenum.

Wolff, T. (2001). Community coalition building - Contemporary practice and research: Introduction. American Journal of Community Psychology, 29, 165-172. 